\title{
Fostering Ethnic Reinvention
}

Gender Impact of Forced Migration on Bantu Somali Refugees in Kenya Invention de l'ethnicité et modification des rapports de genre chez les réfugiés somali du Kenya

\section{Francesca Declich}

\section{OpenEdition}

\section{Journals}

\section{Electronic version}

URL: http://journals.openedition.org/etudesafricaines/2

DOI: 10.4000/etudesafricaines. 2

ISSN: $1777-5353$

\section{Publisher}

Éditions de l'EHESS

\section{Printed version}

Date of publication: 1 January 2000

Number of pages: $25-54$

ISBN: 978-2-7132-1346-5

ISSN: 0008-0055

\section{Electronic reference}

Francesca Declich, « Fostering Ethnic Reinvention », Cahiers d'études africaines [Online], 157 | 2000 Online since 20 November 2013, connection on 19 April 2019. URL : http://journals.openedition.org/ etudesafricaines/2 ; DOI : 10.4000/etudesafricaines.2 


\section{Francesca Declich}

\section{Fostering Ethnic Reinvention:

\author{
Gender Impact of Forced Migration
} on Bantu Somali Refugees in Kenya*}

This article assumes the process of displacement due to natural or human generated disasters, as a condition which, in spite of constantly changing contexts, entails similar structural characteristics generally determined by the constant way international aid is provided. Such structural aspects influence the negotiation of power within groups by occupying spaces of uncertainty created by the very process of forced displacement. In fact, despite the different geographical, historical and political conditions in each case, a change in production/reproduction relationships often, if temporarily, occurs within a group for some period of time following displacement. It is during this very period that the patterns to control and manage people in conditions of displacement are often very similar everywhere as applied by humanitarian agencies; such standard patterns may have a strong influence in terms of inter-gender power relations. In other words, I argue that the periods in which refugees do not control the means of production are the periods in which aid providers, who belong to an outside and international context, may wield the greatest influence. As control of production is continuously renegotiated between genders, impact on gender relations and construction is to be expected in forced migration processes, especially when people receive humanitarian aid during such processes.

I argue that the very pattern through which humanitarian aid is offered provides similarities and constants in situations which otherwise may vary greatly from each other. One characteristic of such similarities is that

* Early versions of this article have been presented on the 24th of May 1995 in Edimburgh, at the conference on "Identity in Africa" (24-26 of November 1995) and at the 2nd Congress of the AISEA (Associazione Italiana di Studi EtnoAntropologici), University of Rome "La Sapienza". An initial introduction from the Refugee Studies Programme of the University of Oxford was important to allow my visit in the camps surrounding Daddab. I thank for helpful comments on this article: Eve Crowley, Doreen Indra and an unnamed referee of the Cahiers d'Études africaines. A welcomed contribution of the French Institute for Research in Africa (IFRA) in Nairobi became available when carrying out fieldwork in Kenya and Tanzania. 
actions, benefits and incentives are directed differently by gender, reproducing, more or less, highly conventional western standards ideologies of what gender relationships should be. Therefore, humanitarian actions may have a differential impact on future development for men and women. In other words, a comparatively uniform "refugee experience" in Africa results largely from becoming a recipient of aid in settlement areas/refugee camps according to some standard criteria.

I define here a system of humanitarian aid provision as a set methods of supplying items and services to a human group considered in condition of urgent help for survival. The system is composed of a number of inputs (food items, non food items and basic services) which are provided according to certain rules by a community of expatriates together with some nationals from the host country. The actions of such community, and the rules used for providing aid, are integral part of the system of inputs offered to the refugees.

The standard inputs produced by the system of aid provision are addressed differently by gender and, therefore, have a differential influence on men and women. The different ways men and women respond and/or strategise in relation to similar inputs from external agencies can be better estimated along the time; strategies and ways to respond may vary according to class, age and education of those involved.

Unfortunately, only a few analyses of such responses in the period following first displacement are available ${ }^{1}$. Most studies which are carried out within a context of development or emergency projects suffer from an epistemological constraint: they describe people who have been observed during a short period of time, without much knowledge of their previous ways of living nor follow up in the next stages. These studies rarely compare what happens to people after the emergency period with what was envisaged in previous reports, because this is not part of their rationale or interests. Studies conducted in emergency projects often attempt to construct "history" based on people's recollections-which are of course themselves situational to the emergency context, and which may not closely parallel either their historical experiences or actions.

In this article, I shall present the case of the Somali Zigula and Shanbara who escaped from war along the Juba River in Somalia. Data were gathered between 1985 and 1988 in Somalia and, later, between 1994 and 1996 during displacement in Kenya and Tanzania's refugee camps. I suggest that this group's loss of control over production of staple food, during the first period of their forced migration, created a condition of weakness and uncertainty which largely determined the process of power negotiations between genders that followed. In such a situation of radical change, some people are endowed with power and some are disempowered. This occurs through micro-mechanisms which give rise to the establishment of new

1. The work of Elizabeth Colson is a very good example of such analyses. 
dynamics between genders. Such micro-mechanisms should be highlighted as much as possible in order to provide key points for a diachronic analysis of the changes that take place in the relations between gender in such situations. Among the Somali Zigula, for instance, it is already apparent that gender power relationships within the group are changing as a result of a certain management of the aforementioned period of uncertainty by humanitarian aid agencies. A renewed gendered construction of ethnicity is part of this process.

\section{Bantu Refugees from Somalia}

Following the onset of the civil war in Mogadishu in the last days of 1990, thousands of people fled from Somalia. By the beginning of October 1992, Kenya hosted approximately 412,000 registered refugees and it was estimated that another 100,000 unregistered refugees were living in the country. More than 300,000 of these were Somalis (Gallagher \& Forbes Martin 1992: 16).

Most of those who fled from the riverine areas surrounding the Juba River poured into refugee camps along the boundaries with Kenya in Liboi and Daddab. Daddab was controlled by UNHCR (United Nation High Commissioner for Refugees) and run through several implementing agencies. The largest flow of refugees occurred in 1992, when gunfights along the Juba River became more frequent. Between September 1991 and June 1992, three camps were opened near the town of Daddab in Northeast Kenya. In March 1994, they hosted 128,144 Somali refugees divided in three settlements by the names of Ifo, Hagardeera and Dagahaley. Out of these, 1,252 in Ifo $^{2}, 3,322$ in Hagardeera ${ }^{3}$ and 5,569 in Dagahaley ${ }^{4}$ were defined in UNHCR's reports as "Bantu Somali" refugees, totalling 10,143 members of such minority group in the camps. Other "Bantu Somali" settled in the Marafa refugee camp close to Mombasa and approximately 3,000 reached Tanzania and were allocated to the refugee camp of Mkuiu (Tanga Region).

\section{Adoption, Patronage, Clientship and Occupational Castes in Somalia}

Before I discuss the present day ethnic classifications and labels it is useful to go back to detailed studies describing some processes which brought

2. Ifo refugee camp. Fact sheet, UNHCR, n.d. See also Ifo Site Profile, UNHCR, October 26th, 1993.

3. Hagardeera refugee camp. Fact sheet, UNHCR, n.d. See also Profile of Hagardeera Refugee Camp, UNHCR, December 14th, 1993.

4. Dagahaley refugee camp. Fact sheet, UNHCR, n.d. See also Dagahaley Refugee Camp. Camp Profile, UnHCR, January, 1994. 
agriculturalist settlers of the Juba and Shebeli Somali Rivers (Shabelle, Shidle, Makanne, Eyle, Elay Baydabo, etc.) to be progressively overwhelmed by pastoral populations arriving from northern areas and seeking accessible water points along the Rivers.

As inquired about in the second and third decade of the twentieth century and, later, diligently described, the struggle over the River access points and, to some extent, to rainfed cultivable lands, gave rise to repeated bloody clashes and violent fighting which resulted in different kinds of agreements between lineages and groups of people (Cerulli 1964: 78). The nature of such agreements have been described in terms of relationships of patronage, adoption and alliance (iskashaato); however, jural and actual nuances of these forms of interaction were a matter of negotiation and depended on the skills in public relations of the individuals, groups and communities involved, on the resources at stake and on the size of the groups involved.

Patronage in Somalia is a relation in which groups of people seek an agreement of mutual dependence although one becomes patron and the other a client. A patronage relationship, for instance, occurs when agriculturalists give to a certain lineage/clan of pastoral people exclusive rights to River access points close to their village; in exchange for such an exclusive license, the agriculturalists may receive an annual payment in animals and a permanent protection against the intrusion of other foreign shepherds who might not respect their cultivated fields while approaching the River access points. The relationship of the agriculturalists Makanne with the pastoralists Badi Caddo is said to have been of this kind, during the first decades of the twentieth century (ibid.: 84), as well as that of the agriculturalists Shidle with the pastoralists Mobileen (ibid.: 78). There are also relationships of patronage between pastoralists; for example, it is reported that scattered Somalis (Harti, Ogaadeen and Marrehaan) entered the lower Juba area as clients of the "Galla" (Oromo) people. Initially, the Somalis looked after the "Galla's" animals. Thereafter, the Somalis' number increased and they gained a foothold: revolted against their patrons and started controlling those lands (ibid.: 79).

Adoption between descent groups named "haliif" (in Arabic) or "arifa" (ibid.: 68), in a mangled Italianised way, was especially widespread among the Somalis Hawiye. This was an agreement through which the adopter (a clan, a lineage or one of the family of the lineage), under request, took complete responsibility for the protection of the adopted; the adopted (person or group), on the other hand, was to refrain from jeopardising the peace of the adopter group (ibid.: 67). Among the Hareyn-as possibly, in most cases of adoption - the adopted formally renounced to their birth place in terms of clan/lineage and promised to accompany the adopter's clan/lineage in peace and war for ever (Lewis 1969: 66). This also entailed a partial or total transferral of blood compensation rights and duties from one's original group to the adopter's clan/lineage (ibid.: 67). The reciprocal obligations entailed by the agreement of adoption could cease for two reasons: 
when an adopted group migrated from the territory and when an adopted group became strong enough to constitute an autonomous ethnic unity, as recognised by the adopter. Of course, power conflicts would also determine the cessation of an adoption (Cerulli 1964: 73). The end of an adoption involved the clearing out of the territory previously granted for agriculture or other purposes by the adopter (ibid.: 67-68). From the adoption system arose several complicated issues in the consuetudinary law and examples of such are reported for the twenties (ibid.: 68, 70-75) and the sixties (Lewis 1969: 72-74). The institution could be used by a group for establishing itself in an area and, thereafter, claiming such territory permanently by force. Moreover, allegiance of an adopted lineage or family with its original clan could continue after many years of permanence in far away areas. When adopted people kept old allegiances with lineages/clans of enemies they became unpleasant and dangerous guests in case of conflicts. Finally, when governments banned the use of tribal criteria from the national legal system, adopted people could try to use their old relations of adoption in order to claim permanent rights over other clans' cultivable lands ${ }^{5}$ again fostering conflicts. Yet, relations of adoption protected some agriculturalists before other regimes of land property were set up in Somalia. For instance, during the Siyaad Barre government, disregarding relations of adoption, tracts of land were expropriated for national purposes (i.e. setting up of state farms, etc.), taken from people who had less links with the lineages/clans of the governments' members, mainly agriculturalist riverine peoples.

During the years, the interactions created through adoption and patronage, fostered certain pastoral people to convert themselves to good farmers by occupying more and more arable land. Along the Shebeli River, Cerulli mentions some such people as: the Hillibi, the Daacud of the Balad area, the Mobileen, the Molkal, the Badi Caddo (Cerulli 1964: 83). Yet, some Somali pastoral groups were adopted in villages of riverine people; for instance, in the Shidle village of Shanloo, along the Shebeli, lived families of Somali Wacesla (ibid.: 82) and in the Zigula village of Mugambo, along the Juba, lived families of Somalis who spoke the Bantu language kizigula.

Therefore, despite the general understanding of what is Somali society, there have been very complex ethnic interactions among pastoralists and agriculturalists in the last centuries; it would be difficult to keep track of all such interactions. These involved the concession of temporary rights over the use of land and territory, but did not necessarily entail that the adopted people (agriculturalists or pastoralists) were the losers (ibid.: 84). In fact, especially before colonial times, a patron/client relationship was one of mutual support in different economic activities or for the control of a territory rather than one of domination of a group over another. Until the

5. See the case reported in LEWIS (1969: 72-74), although the case is mentioned to argue another point. 
present time a "distinction is made between those born into a clan and those who have become members by adoption" (Helander 1988: 133). However, case studies from the Hubeer (ibid.: 43) and the Hareyn (Lewis 1969: 68) show that in many cases those who have been adopted outnumber the others.

Adoptions also involved people of those occupational castes considered inferior to the others. An analysis made by Cerulli (1964: 90) points out at low castes people, as descendants of those subdued during the successive invasions of the Horn of Africa in the last centuries. No conqueror completely destroyed the enemy nor was free from contacts and intermarriages with the defeated people. This occurred even though the latter were put in an inferior jural condition (ibid.: 88). Several different kinds of groups have been assimilated to such low castes on the base of their jural inferior situation; such groups have included corporation of people practising special jobs considered vile and suspect, such as blacksmiths, wood workers, potters, tanners, magicians, shoe makers, hunters and gatherers and sometimes fishermen. Therefore, according to Cerulli, people belonging to low castes share similarities in development and historical formation rather than linguistic, cultural or geographic origins (id. 1959: 113). The names of the most well known low castes in Somalia are Ybir, Midgan, Tumal, Gacansibir, Muusa Deryo, Ribi, Bon, Kabtol, etc. The names are not accurate if seen as referring to specific lineages or occupations, rather, the way people from different occupational castes are named is positional. It depends much on the geographic area of the Somali country where they live and the lineage membership of those who speak about them. For instance, at the beginning of the 1920, there were blacksmiths Tumal in Mogadishu who considered themselves as poor descendants of the Ajuraan ${ }^{6}$ (id. 1964: 91-92) and blacksmiths called Gacansibir among the Marrehaan of the Juba; yet, Muusa Deryo among the Rahanwiin were potters and blacksmiths unlike the Muusa Deryo of the Habar Awal (id. 1959: 101-113). Hunters and gatherers along the Juba River in 1985 were called Bon by both Shanbara and Zigula and only very few intermarriages would occur.

Nevertheless, Shanbara reported that at the beginning of their settlement in the Gosha area a group of men abducted women from a village of the Bon people and married them ${ }^{7}$.

A common characteristic of the occupational castes is that they have established long term patron/client relationships with one of the predominant lineage in the area where they live. Such relationship entails consuetudinary agreements with the patrons as regards payment of bloodwealth, dispute resolution and marriage rules which vary from group to group. Basically, because their specialised work is necessary in any lineage, people from such castes usually have long term relations of adoption with stronger clans. Moreover, they are not in a large number nor have strength enough

6. The Ajuraan were patrons of the Shebeli valley North of Mogadishu.

7. Fieldnotes, 1985. 
to defend themselves alone. As adopted people, low castes cannot take political initiatives but enjoy some sort of protection depending on the lineage/clan of their patrons ${ }^{8}$. In the past, low caste people and slaves held different legal status (Cerulli 1959: 19-29) which varied according to lineages and geographical areas. Often was recognised a real blood compensation for the death of low caste people (id. 1964: 72). It is impossible to dwell on the analysis of all such jural differences as regards people scattered in so many different areas of Somalia. It would be enough to say that, despite conspicuous differences within their legal status at the beginning of the twentieth century, low castes, freed slaves and slaves were held an unequal and inferior jural condition as compared to those considered ethnic Somali.

During the twentieth century this local system of distinction and social stratification, initially based on a need for regulating access to natural resources as well as for managing specialisation of occupations, has been modified and divisions have been stressed as well as reinforced to fit within different ruling systems.

\section{Rationale for Labelling: Past and Present}

Following the substantial flow of refugees since the end of 1990, for the first time the international community appeared to became aware of the existence of Bantu among the Somalis. However, in the history of Somalia, this sort of ethnic category had been used by colonialists for political purposes joining together all those Somali people who were skilled in farming or in other practical works (people belonging to the occupational castes). Such categorisation reflected and certainly emphasised an existing local ideology which considers all agriculturalists of the Rivers (Shabelle, Shidle, Makanne, Eyle, Elay Baydabo, Shanbara, Zigula, Gosha ${ }^{9}$, Mushunguli ${ }^{10}$, etc.) together with occupational castes (Ybir, Midgan, Tumal, Gacansibir, Muusa Deryo, Ribi, Bon, Kabtol, etc.) inferior groups as compared to pastoralists. Disregard of both kind of people was part of the ideology which magnified the image of pastoral nomads. Among pastoralists could be found the bilis, i.e. "nobles" and among agriculturalists the "slaves" or "ex-slaves".

In the first decades of the twentieth century the Italian colonialists reinforced such an ideology by mistakenly emphasising the pastoralists power

8. Cerulli gives some information about the jural status of such castes among the Majeerteen (1959: 24-29) and the Marrehaan (ibid.: 77-82) and the Hawiye (ibid.: 283-300).

9. The name Gosha points out at all riverine people of the Juba River.

10. Mushunguli is a mangled name for mzigula, i.e. person belonging to the Zigula people; the term has been widely used to point out at all riverine people of the Juba River, sometimes in a derogatory sense. 
over supposedly ex-slaves. The fact that Cerulli puts forward a great deal of evidence against the very inaccuracy of calling "liberti", i.e. freed slaves, the whole "negro" populations of the Shebeli and Juba Rivers corroborates the argument. It seems that the diplomat was opposing a very common view among colonial officers of the times ${ }^{11}$.

Despite internal divisions and distinctions, at the beginning of this century Italian colonialists paid special attention to the descendants from slaves for their skill in farming. The following paragraph illustrates how this characterisation was linked to the problem of recruiting agricultural manpower: "Hand power in the Benadir is scarce for a complex series of reasons of a moral, economic and demographic kind: [. . .]overall there is a natural slothfulness of pure Somalis towards work in the fields: only slaves and freed slaves practice this dishonourable activity; it is only among them that we gather the small amount of manpower which is available." 12

The categorisation of these people according to economic activities, which was drawn in a local existing distinction, was consistent with the viewpoint of the Europeans of the colony. This consonance resulted in the reinforcement of divisions among people because Italians needed farmers for agriculture in the colony. All free people who farmed by tradition, whether slaves or ex-slaves or agriculturalists who had always been free, were basically included into the same category.

Later, from 1925 to the end of Fascist Rule in Somalia determined in 1941 by the upwind of the British Military Administration, Italians continued to base ethnic categorisations on economic activities, in order to "recruit" people into forced labour to apparently build public infrastructures (Serrazanetti 1933: 20) and work on farms (Del Boca 1992: 203).

Although they knew that many different lineages and group identities existed among the riverine agriculturalists, Italians did not hesitate to lump them all together into a unique whole of those who could be of some use as forced manpower. An informant imitated an Italian scolding Gosha farmers who attempted to escape conscription with the following words: "I do not accept your saying 'I am a Mushunguli', 'I am a Bartire', 'I am a Shabelle', 'I am a Cawlyahan', 'I am a Marexan'. These do not exist for you. You are lying. You are all Mushunguli Mayasid [Bantu]. You have to participate [in forced labour]" (Besteman 1994: 52).

In reality, for the farmers who live along the Rivers in Somalia, claiming membership in a Somali lineage, such as Marrehaan, Cawliyahan, Bartire, etc., can mean two different things: belonging to a group which is under

11. Such argument is supported in all three Cerulli's volumes titled Somalia (1957; 1959 ; 1964). However, a direct statement can be found in CERULLI (1964: 8788). The author describes the nature and the historical development of certain relations of patronage and adoptions established between stable agriculturalists "negros" and pastoral lineages (ibid.: 75-84).

12. In Bollettino della Societa' Geografica Italiana, 73, 1910 (English translation of the author). 
a relation of adoption, patronage or alliance with a certain Somali lineage/ clan or descending from ancestors who had been slaves of people from that lineage. In fact, people might call themselves with the name of their masters; this was, for example, the case of those who had been taken as slaves when they were children, because they did not know their original family names ${ }^{13}$. In the first instance, the claim can aim at defending one's rights as people protected by a Somali lineage/clan because in some sort of alliance with it or because descendants of ex-slaves of such lineage/clan. On the other hand, for those Zigula who had obtained their freedom in the territory of the Juba River by winning the war over the Ogaadeen at the turn of the century, the claim of being a Mushunguli (a mangled way of saying Mzigula, i.e. Zigula person) could be part of a strategy to obtain the same rights as "pure Somalis" who were not forced to work in the Italian farms. In other words, claiming a Mushunguli identity might aim at enabling supposedly slave descendants to claim the same status as descendants from free people, like the "pure Somalis". Under such claim lies the very criteria that authority and dominant position of a group could be based on the autonomous control of a territory by a group and not on the status of people by descent. Finally, the very fact that people claimed such alliances in front of the Italian officer suggests that conscription to forced labour was organised by stressing traditional criteria of alliance and authority; the Somalis with pastoral origins were co-opted in subduing to such labour people with agriculturalist origins.

Unfortunately, the nature of slavery in Somalia at the turn of the century has not been studied in depth as yet; however, scattered information suggests that mobility among social strata followed criteria nowadays imponderable. For instance, among the Majeerteen the sultan could free a male slave and such slave could then marry a free Somali woman, unlike other freed slaves (Cerulli 1964: 24). And yet, Borana captives were made slaves by the Marrehaan: however, if a Borana woman was taken as a captive, then married a Marrehaan and thereafter delivered a child she became free and equal to any other wife of the Marrehaan (id. 1959: 83).

The fact that a certain mobility from one social strata to another for individuals and groups existed in Somalia has been overlooked; all "agriculturalists" were homogenised under the label of "liberti", "freed slaves", and became farmers who could be forced into labour.

Along the Shebeli and Juba Rivers, agriculturalists men and women, all considered to be slave descendants or related peoples, were recruited through forced corvées and mostly under the Bertello farming contract (Del Boca 1992). So called "pure Somalis", possibly bilis or "nobles" were to choose people belonging to those groups who were under their control to

13. Nowadays, people who act this way are called in Somali shegato. This term in Somalia is also used to point out at recent patron/client relationships (LEWIS 1969: 86). 
be forced into such corvées, under pressure of the colonial government. Chiefs of "docile" and "dedicated" clans had to send a set contribution of manpower to the estates (Serrazanetti 1933: 10-11). In other words, Italian colonialism supported the ethnic division of the Somali population by economic activities, which stigmatised agriculturalists in many aspects.

A singular phenomenon which reinforced only one kind of ethnic identity created a gendered and unequal one: agriculturalists men were co-opted into a policy that restricted agriculturalist women's freedom in marriages. Men to be conscripted into forced labour were given the right to choose any woman they wanted as a wife, without her consent or that of her relatives (Declich 1995b: 111-113; Menkhaus 1989: 259). New young couples without children were preferred in the estates. The regulation waved new husbands from paying marriage transactions for the spouses (Serrazanetti 1933: 11). Fathers were co-opted into ceding their daughters under threat of being conscripted themselves or their sons (ibid.). It is amazing that, in order to restrain reactions of men against conscription such an abuse of power over women should be authorised to them. Indeed, several demonstrations against conscription were held in the lower Juba area ${ }^{14}$; yet, many conscripted escaped from estates every where in Somalia (Serrazanetti 1933); however, as informants from the Juba area hinted at with irony, without the company of a woman most young men would have run away from conscription.

With Independence (1960) and following the Socialist Revolution (1969), some expressions of tribalism were banned and laws prohibited the use of words which highlighted or signified racial disdain such as addon (slave), Midgan and Ybir (names of some occupational castes), and jareer (i.e. person with curly hair, hinting at a progeny of slaves $)^{15}$. Despite the apparent effort to eliminate racial discrimination within the country, in practice discrimination continued and worsened with the eruption of the civil war at the end of $1990^{16}$.

A local system of oppositions among the others characterises nowadays membership in groups and is matter of distinction within people. A first subdivision distinguishes jareer from jileec. The jareer are those who are said to have curly hair and large noses; these features clearly identify them as originating from East Africa, and associates them with descendants from slaves who are believed to deserve scorn. The jileec are said to be Somalis with straight hair and a long-limbed build. The classification jareer/jileec is based on physical characteristics although not all those who in principle should look like jileec because of clan affiliation have a clear semblance

14. Fieldnotes, 1988.

15. See "Legge sull'eliminazione di alcuni termini indicanti sottocaste", in Bollettino Ufficiale, Legge No. 14, 23 maggio 1961, Mogadiscio. See also Pestalozza (1973); and Prima carta della Rivoluzione, 12 Ottobre 1969, art. 5.

16. See, for instance, "Land Tenure, the Creation of Famine, and Prospects for Peace in Somalia", African Rights, October, 1993. 
of jileec. In fact, if ideally intermarriages between jileec and jareer do not occur, in practice during the centuries several dynamics, among which some have been described above, have fostered an intermingling of the members of the groups in different ways according to the geographical and political circumstances. The jareer/jileec classification, therefore, is an imprecise one but remains a sensitive issue in terms of identity for the Somali people: it takes a positional meaning depending on the geographical and cultural context in which it is mentioned. For somebody living along the Juba River a jareer who had sleek hair, because of one of her/is ancestors, might be considered slightly an outsider if not proving special commitment with the jareer's way of life. On the other hand, the very fact of living among jareer makes of such person a jareer in the view of jileec. The jareer are believed to come from agricultural families, whereas the jileec are most often of pastoralist origin. Before the outburst of the civil war in 1990 such distinctions were already stereotypical. However, in the context of daily life relationships, these continued to be powerful distinctions which were used to marginalise jareer from access to jobs, benefits, education and family networks. Yet, descendants from families of ex-slaves in Mogadishu enjoyed some form of protection from the descendants of their relatives' masters.

Among the jareer of the riverine area of the Juba, however, other oppositions existed and people classified themselves into many other categories with specific positive and negative connotations. Oral traditions of the Zigulas, for instance, record their liberation from enslavement by escaping en masse, using this to explain why they have kept their Zigula language (Declich 1995b). The Somali Zigula-people who speak the Zigula language - call those who no longer speak a Bantu language "Mahaway", which is a scoff at their pronunciation of the Somali language. The latter, on the other hand, call themselves Shanbara or Shanbarani which means, descendants from five original brothers who belonged to east African groups such as the Yao, Makua, Nyasa, Nyamwesi and others (id. 1987).

The word "Bantu" to identify riverine peoples of Somalia was used in colonial times by racist anthropologists, like Puccioni (1937). The term "Negro" was instead used by more accurate Italian colonial officers, among whom the most famous are the lawyer Massimo Colucci (1924) and the orientalist and diplomat Enrico Cerulli. The latter, was in charge of studying Somali dialects at the R. Istituto Orientale in Naples in 1916 (Cerulli 1959: 9) and spent years in the Shebeli valley in Somalia during the first half of the twentieth century (1919-1922). As he attended a great deal of dispute settlements in those years, his reports are invaluable for the details he attaches to the many cases he describes. Puccioni was a member of the school of anthropology in Florence which advocated scientific reasons for the inferiority of the Bantu as a human "race". Cerulli, using a more accurate approach to the study of the Somali people, clarifies that not all Somali "Bantu" were, indeed, descendants from slaves; rather, they were farmers 
who had originally inhabited the riverine areas that were later overwhelmed by Galla (i.e. Oromo) and further Somali (Cushitic language speaker) pastoral populations and runaway slaves (id. 1957: 161-163). The fact that they no longer spoke Bantu-based languages did not mean that they had been slaves. As such, Bantu had become a minority in an area largely inhabited by pastoral Somalis and because of their physical semblance to those who had been brought as slaves from the East African Coast, they had all been identified as descendants of slaves.

Nowadays, within the civil war in Somalia and in the refugee camps, several factors foster the creation of a new ethnic consciousness and its internalisation by those who have been called jareer in Somalia. One such factor is the definition of different levels and strata of beneficiaries for the distribution of humanitarian aid, with the aim of providing equal access to all, in the refugee camps.

\section{The Construction of Bantu Ethnicity in Refugee Camps}

As they arrive in reception areas newcomers are divided into groups usually by lineage, ethnic group, or village of origin (Declich 1995a) and, therefore, "if necessary, by clan" (Gallagher \& Forbes Martin 1992: 18). The registration form which is used by UNHCR includes the tribe/clan/sub-clan as information to be gathered about the people who register ${ }^{17}$. In much literature about Africa the very concept of "tribe" or "clan" has been largely criticised for being inadequate, imprecise and a result of colonialists' constructions (Iliffe 1979; Hobsbawn \& Ranger 1984; Southall 1970; Vail 1989). Although the meaning of the words "tribe" and "clan" may still be unclear, such classification, apparently, is nonetheless useful in order to confer some control and order to the camps, as well as to allow people who trust each other to settle together. Nevertheless, the use of such classifications definitely reinforces certain criteria of hierarchy by lineages. Somalis from a pastoral background are known to be subdivided into patrilineages and the process of registration in the camps may strengthen patrilineal ties, even among those Somali groups for which such ties are not otherwise very important.

People who do not have clear affiliation to Somali patrilineages and who have curly hair are now classified through a process of registration as "Bantu" by the refugee camps authorities. Such classification, has been applied by the UNHCR despite the fact that only a few of them actually speak a Bantu-based language (Declich 1995b). Ironically, the "Bantu" categorisation helps the jareer to increase their visibility in the camps, in which they would have been otherwise marginalised because of racial discrimination. However, the category "Bantu" was completely unknown

17. Branch Office for Kenya-Nairobi, Registration Form, UNHCR, n.d. 
to them before arriving in the camps. People I knew from Somalia, had never heard the word "Bantu" before, and said "we are now Bantu, we, the Zigula, are called Bantu here in the camp". In an attempt to endow the jareer with some ethnic dignity and recognition, a field officer classified the Bantu as "Mushunguli" (Lehman 1993); a project manager identified them as Shanbarani-a name farmers of the Juba River who only speak Somali language give to themselves-, because the women she interviewed identified her group as such and distinguished such group from other Bantu in the camp (Musse 1993: 13). The different names people have used for themselves in different contexts in Somalia have been discussed elsewhere (Declich 1987; 1995b).

In the camps close to Daddab, the fact that Bantu are considered to be a different sort of people from pastoralist Somalis allows camp authorities to identify them as one vulnerable group. Otherwise, they would risk not receiving the benefits to be distributed. If the Bantu were mixed or hidden among other Somalis, they would risk starvation, because their food would be simply looted. Due to their ill-regarded descent, they have been poorly treated by other Somalis in Somalia and in the camps and have became preferred target of bandits. In keeping with occasional reports by observers that a large number of Bantu have arrived at the frontier in very weak shape (Gallagher \& Forbes Martin 1992: 19), conversations and reports of officers working along the Juba River during the war ${ }^{18}$ confirm that the newlyascribed Bantu categorisation-that had become widespread after 1990 as a result of forced displacement-has been important in affording them visibility.

The label of "Bantu", however, has no precise meaning aside from singling out those who do not belong to Somali patrilineages, and thus, is a sort of device used by humanitarian agencies in order to identify this particular kind of beneficiary. On the other side, those who are called Bantu, even if they never defined themselves as such before then, for the first time in the camps meet vested interests in being pulled together under the same umbrella name. Not the jareer classification, as it was used in Somalia, nor the fact of being all agriculturalists, had been strong enough reasons to foster a common consciousness among these marginalised people in Somalia. In the camps, however, it has become clear that these people are a minority group and would have problems in receiving benefits if these were to be channelled through key persons among the Somali patrilineages.

Moreover, such non-affiliation has already put them at risk in Kenya due to lack of responsibility/guarantee in terms of bloodwealth. At the beginning of their stay in the camps, the Bantu became an easier target than others for bandits and/or thieves and women were raped in such occasions.

18. "The nightmare continues... Abuses against Somali Refugees in Kenya", African Rights, September, 1993. See also "Somalia. Human Rights Abuses by the United Nations Forces", African Rights, July, 1993. 
Different groups of bandits and thieves, both Kenyans and Somalis, were raiding the refugee camps especially attracted by the distribution of items. In order to defend themselves, the Bantu had to arrange to reside next to each other in the three camps, and, autonomously fenced their quarters with thorny shrubs to constitute fortified compounds ${ }^{19}$ (Lehman 1993: 6). Moreover, they made bows and arrows and kept stores of stones to scare bandits and thieves who, for this reason, became afraid to approach their compounds.

\section{Downplaying Female Gender in the New Ethnic Construction}

Undoubtedly, identifying the Bantu as a different ethnic group from other Somalis may help them to be protected, and to receive a share of the benefits provided by humanitarian agencies which they need in order to survive displacement. In other words, this strategy worked as a way to defend their access to benefits, incentives and, ultimately, human rights. In fact, by being allowed to settle together in one area of the camp, the so-called Bantu can benefit from channels of distribution managed by their own representatives, rather than by other Somali groups. However, it is exactly by claiming such equal access to benefits, combined with the "emergency" situation, that officers in the camp make choices which downplay the importance of women's roles in crucial decision making processes. I would like to dwell on the usual procedure that officers apply to foster some participation in decision making in the refugee camps. This entails singling out those seen to be responsible persons, who wield some authority and control over groups of people, to be recognised as heads of clusters of compounds within the camps. They become councillors of sorts, who represent the wishes of the groups. Using such a method and participatory approach, a group of Bantu male elders were settled together in the refugee camp of Dagahaley.

In March 1994, I had the chance to meet them. They were identified as the ones responsible for clan subdivisions among the Bantu refugees. The elders had prepared a statement about their wish to be resettled in Tanzania, where they hoped to find land, start agriculture, and reconstruct a living. Yet, also to some UNHCR representatives resettlement in an African country appeared to be a concrete, plausible, and durable alternative to the forced displacement of Somali Bantu. The area along the Juba River was not peaceful enough for repatriation, nor was a safer situation envisaged in the near future. Some Bantu lands had been invaded and most of the Bantu who remained were forced to share crops with newly arrived masters ${ }^{20}$. Moreover, the racial discrimination these people had suffered in Somalia and would have to face again if they returned there, were other considerations. The concern of the UNHCR's officers for this marginal group was

19. See Africa Report, May-June, 1995: 25.

20. Ibid.: 5 . 
perfectly understandable and praiseworthy and a good reason for considering their resettlement in another area where they could practice agriculture again. Daddab is located in a dry area where scarcity of water prevents cultivations from taking place on a large scale. It is likely that most of the Bantu, if asked, would have endorsed the idea of finding a resettlement area in another African country for their families.

What was questionable, however, was the criteria of "representativeness" which was used to gather this group of male elders. The elders were supposed to represent each of the lineages/tribes/clans, or whatsoever these unexplained words meant, among the Bantu; the nature of such "ethnic" sections for the Bantu was not clear to the field officers of the camp. Yet, the Bantu themselves, had learned in Somalia that it was safer to keep underneath, without disclosing, their own traditional ways of being; rather, they should adapt publicly to what they were requested to be in order to be accepted among the Somali (Declich 1995b). The officers, therefore, assumed that, at registration, new arrivals to the camp declared their clanic subdivision, and that these were structured, more or less, as they were among Somalis. The assumption was that their "clans" must have been something like patrilineages. Accordingly, in order to foster a participation process representatives should be selected by field officers for each of the subdivisions (mviko and/or kolwa) of the "Bantu": Makua, Yao, Nyasa, Zigula, Zalamo, etc. The point is that these "representatives" had never been recognised as such in Somalia because a pyramidal structure based on linear descent did not exist. No one, for example, during fieldwork in Somalia had ever claimed to be the chief of the Zalamo subdivision, which was a very small group of people. I suspect that the name Zalamo was, possibly, a loan word from the Tanzanian group living in the vicinity of Dar-es-Salaam, with whom the Bantu of the camp attempted to establish a fictive connection. In other words, in consideration of previous data about them in Somalia, I had the clear impression that through the camp's experience those elders had been given the chance to negotiate their own power space within their group.

The choice which the officers made, although driven by an understandably scarce knowledge of the kinship system of the Bantu, seemed to me even more cryptic because I knew the nature of the lineage system among the so-called "Bantu". These Bantu do not have patrilineages, nor do they have chiefs who wield power over people of the same patri-lines. The mviko groups are mostly matri-kin groupings, namely, group of people united by the fact of recognising common female ancestors, deputed to the management and organisation of mviko rituals; the heads of such rituals are not necessarily men and most people can claim belongings to mviko of the father's and mother's line (id. 1994: 199, 203-204; 1995b: 107-108). As rituals are important in a public context, mainly because of their prophetic aspects, people involved in the organisation of such rituals, men or women, have a certain influence, sometimes a strong one, in the public life of their 
group. From an individual point of view, although the matri-kin grouping of the mother is the most important to anybody's life, people can also claim belonging to the matri-kin grouping of the father, depending on the situation and the need for certain rituals. While the kinship system provides an opportunity to emphasise both the mother's and father's lines, in the camp only the father's line was given recognition by the UNHCR authority.

One could claim that all criteria of representativeness are questionable in one way or another because they always exclude someone from direct decision making; yet, some sort of screening, as well as negotiation of power, occurs in any case. This commonly occurs among refugees. For instance a recent article argues that the elite of refugees from Burundi eventually acquire a special role (Sommers 1995). However, it is not at all clear why women should be the ones who become marginal in the new invention of political representatives.

Certainly the plight, constraints and risks of remaining in the vicinity of the camps and the general context has reinforced the common feelings of Bantu men and women, that they were all once marginalised, and that they were sharing similar needs and desires for the future. It was the first time, in fact, since fieldwork in Somalia, that I had seen Zigula and Shanb$\operatorname{ara}^{21}$ joining together towards reaching the same aim and supporting the same requests in a non Muslim religious context. During peaceful times in Somalia, divisions were also emphasised, at times (Declich 1995b), in order to describe one's identity and difference. However, for some reason, possibly shaped by the situation of emergency, women in such a new ethnic unity were not provided for as public actors, nor even given the chance. In other words, a new ethnic invention was taking place and male elders were called to publicly construct it, leaving apart women.

When such processes occur in the field, it is difficult to disentangle what really happened while the participatory process was being established. If questioned about the way the elder representatives were selected in a group, managers commonly give many good reasons why men had to be chosen, neglecting women. Explanations such as ". . .when we did ask for representatives from the Bantu, we were pointed toward these men", or "women would have been more at risk if they were put in such a group of elders" or "this matter was a concern of the male elders and we got them together in order to give them voice" or "the issue of resettlement is such a difficult one that there is more chance to succeed if male elders present the requests for resettlement" are put forward. However, by knowing the nature of matri-kin groupings among the Bantu and the non-existence of patrilineages like those of other Somalis, a question arises about whether none of the field officers 1) thought about looking for both, women and men representatives and 2) knew that women, as well as men, discuss whether they prefer to be resettled in Tanzania or somewhere else. More-

21. For clarifications about such ethnic groups see DeCLICH (1995b and 1987). 
over, women were among the people who most felt at risk of being raped in the camps, especially if they found themselves without partners; it would seem logical to have female elder representative of them to be involved in decisions about leaving the camp.

At any rate, as a result of all these conditions, the group of elders who were called together to analyse the feasibility or interest of a goal such as a group resettlement, only included men. In other words, no women elders were summoned to discuss the issue nor were women elders consulted to give their point of view on the idea of resettlement for the entire group. Women were left to speak among themselves about possible resettlement without be given a public space to express so, unlike male elders. The pattern of male representation established among the Somali Zigula during colonial time and followed by the Somali governments was repeated by representatives of the international community in the very person of the UNHCR'a officers.

Besides the actual marginalisation women experience in such a decision making context for the specific issue of resettlement of the group, an important point is the influence such a choice may have on those women for the future. Elder and younger mostly uneducated women who for the first time enter an "international" context or community so directly may believe that in what they see as "modern" social contexts is not appropriate that women decide over the movement of their group or have not the right to do so, as it is shown to them by the officers of the humanitarian aid system. For the first time in centuries, the Bantu found themselves in a context where they are not discriminated against as a group. This brought about a relaxation of social tensions within the Bantu community so that, for example, women did not pay much attention to their public role being downplayed.

The point is how influential can be such a negligence over the confidence of those elder and younger women as regards the appropriateness of their actions in the new international context, their appropriateness in such context and their right to decide over the movement of the entire group.

In other words, the crucial choice of neglecting women elders was made with the commendable aims of supporting the rights of the "Bantu" group to seek a durable solution to displacement and of encouraging participation within the camp's decision making system. Nevertheless, this choice had influential structural effects on power relations between genders within the public domain.

Whether unintentional or for reasons deemed to be acceptable, the organised provision of international humanitarian aid wielded considerable power in the group's gender relations, affecting both authority and personal identity. First, the procedure recognised the authority of male elders as important, while ignoring female elders in the camp; in fact, male elders were called to discuss the future plans and movements of the whole group in a plight, whereas female elders were not consulted and, therefore, excluded from public authority, with few chances to reverse the decisions. In the 
"Bantu" villages in Somalia, there were certain aged women with special authority as regards either ritual performances or other activities at the village level. It is not clear the reason why this sort of leaders were not singled out rather a new sort of ethnic chiefs was supported and given authority through the participation exercise. Secondly, only one kind of individual identity was reinforced and imbued with the status of being "relevant": that which highlights membership in matri-kin groupings, as if they were patrilineages. In other words, the personal identity which is recognised as relevant within the camp is one for which the representative must be a male elder. Importance was attributed to the matri-kin group of the father, rather than the reverse.

In conclusion, a rationale which was, perhaps, unconscious, underlined the procedure for managing camp's issues. Camp personnel assumed first, that the "clanic" system of the Bantu, whatever this could mean, was strictly patrilineal, and second that, in patrilineal systems, women have no rights or choices to decisions about where to move with the family or group in future years. This of course would even be a misunderstanding in treating the actual patrilineal Somalis this way. All these assumptions, embedded in the procedural system of the UNHCR, concretely disempowered women in their possible future "resettlement" in Tanzania or elsewhere. Ironically, this happened also to Bantu speakers among the Somali Bantu, such as the Zigula, who maintain strong oral traditions about their previous forced displacements. In such traditions, women had an important role: the most famous personality in their oral narratives is a woman heroine, Wanankhucha, who lead the largest groups of them away from slavery. She is said to have been a prophet and diviner (mganga) who organised the flight from the Somali villages where the Zigula had been captives. She is remembered as having fostered community feeling among the Zigula by organising repeated performances of traditional Zigula songs. During the flight she was able to help the Zigula avoid danger by means of her divination and visions (ibid.: 105-108; Cassanelli 1987: 221; Grottanelli 1953).

\section{Powerlessness and Persecution of Women by Rape}

In interviews with women and men in the refugee camps, most of whom had been my acquaintances in Somalia five to eight years previously, the major factors which they then asserted provoked their flight from Somalia became clear. Especially, at the end of 1991 and early 1992, raids by armed thieves and bandits increased. Refugees remembered that, in order to obtain money, food, clothes and other available items, bandits did not hesitate to commit crimes of many sorts and would threaten, kill, and/or if the victim was a woman, rape, those who did not surrender.

Rape had become so frequent that, whenever women left the village to fetch firewood, they risked multiple rape. Almost all of the twenty women 
interviewed had been raped once, yet, parties of bandits commonly groupraped individual women. Another way to convince victims to surrender their property was to rape a woman in front of her relatives. Description of the brutal cases which occurred would be endless and I only mention one such narrative story here. One woman recounted that she would never forget the image of her friends chased by bandits. They were two sisters one of whom was pregnant. The women attempted to escape from gunmen, who wanted to rape them, by running towards the river. The pregnant sister could not run fast enough and was shot dead; the other sister, however, managed to escape by crossing the crocodile-infested water. Suffice it to say that rape was always mentioned by both women and men as a very good reason to seek a safer home.

A male acquaintance of mine from Somalia explained why he had decided to flee. After repeated theft of food from his household, the choice was to flee or to remain at home without food and endure the regular rape of young women (daughters, wives, nieces and granddaughters) before his eyes. Adolescent females of thirteen to fifteen years of age were at the greatest risk of rape. Bandits generally preferred to rape young women. If they happened to arrive at night, bandits would rape both younger and older women, but if they arrived during the day they would only pick the younger ones. This acquaintance reported that before the 1992, when he flew from the Juba, in his village of origin, not less than two hundred women were raped out of approximately 1,500 female inhabitants. He warned me that many women do not admit to having been raped, because they are ashamed.

Although, in 1994, the camps surrounding Daddab were still rather insecure for women, who continued to be raped when they left the camp to collect firewood or when bandits would attack the camp to steal ${ }^{22}$, such sexual persecution seemed to be less common than when the refugees were settled along the Juba River.

Another striking memory was that bandits would steal everything, even clothes, often leaving the victim almost naked. More than one woman claimed that her clothes had been stolen after she had been raped. This practice demonstrates that assailants had reached an exceptional and excessive level of cruelty. Leaving someone who has already been abused, without anything, even clothes, marks a wish to render this person completely defenceless, i.e. unable even to present herself among other human beings.

I was told that a new cloth was one of the very few commodities that people, who could prepare their "luggage" before escaping from Somalia, carried with them; in order to avoid theft, this was hidden among the old rags they used to wear in Kisimayu. The possibility of wearing a nice,

22. See Information Bulletin, UNHCR, February 1994: 7; Refugee Women Victims of Violence. A Special Project by UNHCR, UNHCR, October 1993: 4; Information Bulletin, unHCR, June 1993: 10. See also Musse (1993). 
clean and "respectable" cloth was viewed as an important part of one's identity. This symbol of clothing parallels its significance among women victims of violence in the refugee camp. As social workers have noted, women who were forced to continue wearing the same clothes in which they had been assaulted, faced severe psychological problems ${ }^{23}$.

The experience of rape and the prospect of facing it again permanently alters women's hopes for the future and, specifically, their plans about where they would like to settle next. One woman said: "We saw such terrible things. They raped everyone; I would like to return to Somalia, but the very idea that the war could begin there again, stops me." Another woman emphasised the point that the memories of the violence that she witnessed and suffered could jeopardise her future pregnancies.

In short, starvation and sexual violence, perceived as persecution were mentioned as the most important factors for fleeing Somalia during war. The rape of women created a context of powerlessness for both men and women during the war. Although sexual persecution was directed towards women, men were also humiliated by being forced to watch their relatives raped in front of them. Such feeling powerlessness was in addition to the usual impotence which characterises life conditions refugee camps.

Some Characteristics of Powerlessness: Alteration of Production/Reproduction Relationships

One characteristic of Somali refugees in Daddab is that they have undergone a process of alteration in the production/reproduction relationships within the group. Refugees in the camp cannot produce for their own consumption nor is any improvement envisaged in the immediate future. This entails different problems depending upon the main economic activity of the Somali group involved. Whatever the main economic activity of the group, whether pastoral or agricultural, people without a means of production are unable to maintain the roles which are usual to gender in daily life. For instance, female farmers who are used to grow vegetables and sell them in the market, find themselves without the activity which allows them some control over their income; male farmers who do not have a plot of land where to grow staple food have no means to provide their wives with the prescribed daily maintenance. Pastoral women without camels are in trouble because their usual activity of distributing and selling milk is not possible any longer and young men are not ascribed their traditional responsibility of grazing cattle in the bush. In other words, most of the activities women and men of different ages perform daily are no longer possible.

In the camps, both pastoral and agricultural people have no work and, almost literally, nothing to do during the day. For agriculturalists in 1994

23. See UNHCR, October 1993: 4, op. cit. 
there was not enough water to practice agriculture, and the few small gardens which had been set up by NGOs to produce vegetables could not be expanded because they consumed too much of the little water resources available in the camp. Traditional means of production for agriculturalists, such as the availability of fertile land to cultivate for both male and female farmers, were not forthcoming. Similarly, pastoral people had no way of maintaining their productive activities: most of the families had lost their camels and cows, and women no longer had goats. Even if all pastoral people had been provided with animals to raise, these activities would not have been sustainable because of obvious environmental constraints. There was neither sufficient water nor grass in the area for many big herds of camels, cattle or sheeps/goats.

For the refugees, permanence in the camps means passing through a stage in which both men and women are deprived of the chance, albeit for insurmountable reasons, to maintain their productive roles. Such conditions put them in a rather weak position. In fact, the absence of productive roles in a refugee camp not only aggravates the lack of food and commodities that could be produced and then exchanged or sold: this absence also causes refugees to lose the daily life context in which their actions have some effects that they can control and to lose the sense that they can support themselves through their own work. In these terms, the very few productive activities in which Somalis could engage affected women and men equally, in terms of the control on their own lives. Although women continued to perform some of their "domestic" activities like cooking and taking care of the children ${ }^{24}$, it should not be underestimated that Somali women, both from a pastoral and an agricultural background, have always played an important role in productive activities as well. This role used to give them some control over the production of food for household consumption, as well as leverage in household decisions; cooking and distributing food that has been autonomously produced is different from doing the same with scarce rations, received from outside authorities. Such a feeling was epitomised by a common saying: "When we go back home we will not even be able to prepare tea for our own pleasure."

The change in the system of supplying goods for their survival created opportunities to renegotiate the control of provision and distribution channels; moreover, also provided a new arena for such renegotiation. This was because the control over resources, which was at the base of power dynamics within the group and between genders, no longer went through the same channels. Moreover, the new channels for distributing goods become arenas in which hopes for a future and survival are at stake.

Individual and social dynamics were transformed by the arrival of convoys carrying food and non-food items for the supply of the camps. In 1994, the number of assaults and attacks on the camps by bandits increased

24. As also reported in Gallagher \& Forbes Martin (1992: 23). 
on the days assigned to food distribution, when distribution vehicles were kidnapped and bandits attacked convoys transporting provisions. It was not only UNHCR that had to adopt measures to control and protect food provisions; each group of refugees and/or families also had to take particular care to defend their supplies. When provisions were available in the households, they had successfully avoided many chances of being stolen. The power wielded by distributors was magnified in relation to the powerlessness existing in the camps.

\section{Distributing Benefits...}

It is precisely in the mechanisms for distributing benefits that outsiders, such as humanitarian and emergency aid agencies, become important and terribly potent in managing new sources of power, in predetermining opportunities and in offering capabilities (Sen 1994: 63-67, 1993: 86-87) to one individual in preference to another. Benefits do not only include goods needed for survival, such as food, housing and cooking material, but also other incentives, such as employment opportunities, which can change a refugee's life forever.

One case in point is illustrated by the story of a Zigula woman who had been a teacher and farmer when she lived in Somalia. I met her again after seven years in the Ifo camp where she was appointed as a social worker, because she knew how to read and write. Among Somali farmers this is a rather rare skill because, after literacy campaigns in the 1970's' the level of education in rural areas was not been maintained; the woman had been educated by missionaries when she was a girl and had been chosen because she was an orphan. Between 1986 and 1988, in many villages of the Lower Juba district in Somalia the schools opened for just a few days due to the low salaries teachers received. As the school was opened only sporadically until the war broke out, the teacher had not practised her skills much in recent years; at the time, I almost doubted that she remembered how to read and write.

After having escaped from Somalia where she had left her husband, however, and after having spent two years in the Ifo refugee camp together with her five children, she had undergone remarkable changes. She spoke much better Italian than she had six years previously in Somalia, was learning some English, and spoke Kiswahili as well. She was eager to find a way for her children to study, because she realised how important such skills had been for her survival after displacement. While working as a social worker, she had been sent to Tanzania for a short training course on bookkeeping and micro-credit for small enterprises; when I offered some money for the time she had spent accompanying me in the camp, she wanted me to show her a dollar bill, because she had never seen one before since mostly only trade men dealt with this currency. She considered whether 
she should ask me for Kenyan shillings or US dollars, and asked if dollars could be used anywhere in the world and if Kenyan shillings were valid in Europe. Moreover, being a social worker, she was in a key position to distribute commodities in the camp. Since it was she who made the lists of the families, she controlled how many items would be distributed to each person on distribution days.

In other words, she used me as an informant since I had no vested interests in manipulating her and she took every opportunity to obtain new or better jobs. As a social worker, she was lucky to find herself in the right position to strategise in the distribution of commodities within the camp and, like other social workers, she played the game. She had been chosen as a social worker because she had the skills and was a single woman with children.

\section{Micro-mechanisms of Empowerment and Disempowerment}

Simple and basic mechanisms like those described (new ethnic construction and job incentives) may appear small and rather irrelevant as compared to the need to solve problems as quickly as possible in the disrupted situation of a refugee camp. Some rationales for actions and choices are based upon the need for moving fast in order to solve problems. Other actions are justified as avoidance of problems connected with including women in the decision making process, whereas particular attention should be given to the effects of empowerment or disempowerment entailed in most actions taken.

Whatever the choices made, in fact, they carry long lasting consequences in the power relations between genders within a group. Many writers ${ }^{25}$ have highlighted the powerlessness that a camp's life entails for male and female refugees. In this context of powerlessness, actions undertaken by those who manage the camps may have the strength to support or devalue certain groups or classes of people. Because people, women in this case, are in so powerless context do not complain nor find opportunities for resisting. The gravity of the situation, combined with the expectations created by the very recognition of a group of male elders by camp authorities could become strong enough reasons for female refugees not to complain about the lack of recognition of their role. This may be true especially for people like the Bantu who, after having been marginalised in their country for more than a century, are particularly pleased that outsiders have finally shown some trust in the group. Their desire for a future without war might be even stronger than for others, as well as their willingness to surrender their traditional power, if they can avoid the persecution they have undergone in the distant and recent past.

25. See one for all Harrell-Bond (1986). 


\section{Tribal Labelling as a Way to Strengthen Patrilineal Hierarchies?}

In a refugee camp, therefore, people are categorised by "tribes", not very differently from the way they were during colonial times, because of insufficient knowledge and for practical reasons on the part of camp authorities. The consequences of labelling, however, may differ according to historical contexts. In Somalia at the beginning of the century, the ethnic categorisation "Bantu" satisfied the need for singling out a class of agricultural labourers. There were no distinctions by gender and such categorisation served, during the Fascist rule in Somalia, to conscript people to forced labour and "Bantu" women to forced marriages and forced labour (Declich 1995b: 111-113). A question rises as to whether a tribal classification should imply supporting the authority of men over women or whether there can be different and more accurate patterns of actions.

In a refugee camp, ethnic classifications seem to satisfy the need for defining beneficiaries of certain commodities (food and non-food items of humanitarian aid in this case), as well as for fostering an "equal" distribution of benefits. However, a tribal label may not meet the interests of all beneficiaries. Rather, humanitarian and international agencies may support or create a new hierarchy among people, through tribal classification, in order to be able to distribute benefits.

In conclusion, humanitarian aid systems act through organising and distributing commodities, food and shelter materials in camps. The benefits distributed (e.g. food, housing, etc.) become not just goods needed for survival, but potential opportunities for camp residents to renegotiate their power, within the camp. Power within the camp, however, may also mean power in the future, after the camp's life.

The situation of powerlessness which is created in a refugee camp endows the humanitarian aid system with considerable power over refugees' lives. In such a context, refugees need recognition from the outside because one of the traditional systems of managing power, based on the control of the means of production, is no longer in their hands. Key positions of control in the distribution of commodities and decision making in the camp become sources of power. When these are held unequally by men and women, such positions already have an a priori influence over the future development of gender relationships within a group. Although people react differently to similar pressures based upon a variety of factors, such as their traditions, cultural background, and historical experience, processes in a refugee camp may favour certain groups and objectives over others. This is especially true with regards to new opportunities and benefits, etc., presented to men and women after displacement. 
Because people respond differently to similar options and opportunities, it is not possible to forecast with certainty subsequent cultural changes; it is important, however, to highlight the micro-dynamics which endow some people with authority and disempower others.

University of Urbino, Urbino, 1997.

\section{BIBLIOGRAPHY}

Allen, T.

1996 In Search of Cool Ground. War, Flight and Homecoming in Northeast Africa (London: James Currey/Africa World Press, United Nations Research Institute for Social Development (UNRISD)).

BADBURY, M.

1993 Peace-enforcement, Peace-making and Peace-building options for resolving the Somali Conflict. An explanatory Report for Oxfam, October.

BASCOM, J.

1995 "The New Nomads: an Overview of Involuntary Migration in Africa", in J. BAKER \& TADE AKIN AINA, eds, The Migration Experience in Africa (Uppsala: Nordic Africa Institute): 197-219.

Besteman, C.

1994 "The Invention of Gosha: Slavery, Colonialism and Stigma in Somali History", in Ali Jimale Ahmed, ed., The Invention of Somalia (Lawrenceville: Redsea Press).

Cassanelli, L. V.

1987 "Social Construction on the Somali Frontier: Bantu Former Slave Communities in the Nineteenth Century", in I. KopytofF, ed., The African Frontier (Bloomington: Indiana University Press): 216-238.

Cerulli, E.

1917 "L'origine delle basse caste della Somalia", in L'Esplorazione Commerciale, 32 .

1934 "Gruppi etnici negri nella Somalia”, in Archivio per l'antropologia e l'etnologia, 64: 177-84.

1957-1964 Somalia. Scritti editi e inediti, vol. I (1957), vol. II (1959), vol. III (1964) (Roma: Istituto Poligrafico dello Stato).

COLucCI, M.

1924 I principi del diritto consuetudinario della Somalia italiana meridionale. I gruppi sociali: la proprieta' (Firenze: La Voce). 
DALEY, P.

1992 "Gender, Displacement and Social Reproduction: Settling Burundi refugees in Western Tanzania", Journal of Refugee Studies, 4: 248-66.

1994 The Situation of Refugees in East Africa, draft of paper presented to the International Research and Advisory Panel (IRAP) conference in Oxford, January.

\section{DeCLICH, F.}

1987 "I Goscia del Medio Giuba. Una etnia di origine Bantu”, Africa, 4 (Roma).

1992 Processo di formazione della identità culturale dei gruppi bantu della Somalia meridionale, Tesi di Dottorato di Riserca (Napoli: Istituto Universitario Orientale).

1993 Unita' di consumo elo unita' di produzione: le households e la loro organizzazione sociale ed economica nei Paesi in via di Sviluppo, Relazione finale di ricerca del Consiglio Nazionale delle Ricerche. Roma. Manuscript).

1994 "Identity, Dance and Islam Among People with Bantu Origins in Riverine Areas of Somalia", in Ali Jimale AHMED, ed., The Invention of Somalia (Lawrenceville: Redsea Press).

1995a “Creazione di etnicita'? Il caso dei 'Bantu' Somali rifugiati in Kenya e Tanzania", paper presented to the II Conference of AISEA (Associazione Italiana di Studi Etno-Antropologici), University "La Sapienza", Roma, 28-30 September.

1995b “'Gendered Narratives', History and Identity: two Centuries along the Juba River among the Zigula and Shanbara", History in Africa, 22: 93-122.

1997 "Migration, War and Adaptive Strategies: the Somali Zigula Migrants and Exiled in Tanzania", paper presented on the 27th of February at the African Studies Centre, Northwestern University, Evanston.

Del BocA, A.

1992 Gli Italiani in Africa Orientale. La conquista dell'Impero (Milano: Laterza).

Gallagher, D. \& Forbes Martin, S.

1992 The Many Faces of the Somali Crisis: Humanitarian Issues in Somalia, Kenya and Ethiopia, Refugee Policy Group, December.

Gasarasi, C. P.

1984 The Tripartite Approach to the Resettlement and Integration of Rural Refugees in Tanzania (Uppsala: The Scandinavian Institute of African Studies, "Research Report, No. 71").

Grottanelli, V. L.

1953 "I Bantu del Giuba nelle tradizioni del Watzegua”, Geographica Elvetica, 8: $249-260$.

HARRELl-Bond, B. E.

1986 Imposing Aid: Emergency Assistance to Refugees (Oxford-New York: Oxford University Press). 
Hasci, N. \& WaLdron, S.

1994 Somali Refugees in the Horn of Africa. State of the Art Literature Review (Uppsala: Nordic Africa Institute, "Studies on Emergencies \& Disaster Relief, Report No 3”).

HELANDER, B.

1988 The Slaughtered Camel: Coping with Fictious Descent among the Hubeer of Southern Somalia, doctoral thesis (Uppsala: University of Uppsala).

Hobsbawn, E. \& Ranger, T. O., eds

1984 The Invention of Tradition (Cambridge: Cambridge University Press).

ILIFFE, J.

1979 A Modern History of Tanganyika (Cambridge-New York: Cambridge University Press).

KEEN, D.

1992 Refugees: Rationing the Right to Life. The Crisis in Emergency Relief (London: Zed Book).

Kibreab, G.

1983 Reflections on the African Refugee Problem: a Critical Analysis of Some Basic Assumptions (Uppsala: The Scandinavian Institute of African Studies, "Research Report No. 67").

LEHMAN, D. J.

1993 Resettlement of the Mushunguli, Somali Refugees of Southeast African Origins, Distributed UNHCR Working Document, Dadaab, Kenya. Manuscript, November.

1995 Somali Refugees of Southeast African Origin: a Proposal for their Resettlement to Mozambique, a draft report presented to the UNHCR at Geneva, November.

LEWIS, I. M.

1969 "From Nomadism to Cultivation: the Expansion of Political Solidarity in Southern Somalia", in M. Douglas \& P. M. Kaberry, eds, Man in Africa (London: Tavistock): 59-77.

MALKKI, L.

1995 "Refugees and Exile: from 'Refugee Studies' to the National Order of Things", Annual Review of Anthropology, 24: 495-523.

Menkhaus, K.

1989 Rural Transformation and the Roots of Underdevelopment in Somalia's Lower Juba Valley, PhD, University of South Carolina.

Moser, C.

1993 Gender Planning and Development (London: Routledge). 
Musse, F.

1993 Women Victims of Violence. Report on Refugee Camps in Kenya, for the UNHCR Branch Office in Nairobi.

Pestalozza, L.

1973 Somalia. Cronaca di una Rivoluzione, 21 ottobre 1969 (Bari: Laterza).

PuCCIONI, N.

1937 Giuba e Oltregiuba. Itinerari della missione della Reale accademia d'Italia (Firenze: Sansoni).

RANGER, T. O.

1984 "The invention of Tradition in Colonial Africa", in E. Hobsbawn \& T. O. RANGER, eds, The Invention of Tradition (Cambridge: Cambridge University Press).

SEN, A.

1985 Commodities and Capabilities (Amsterdam: North-Holland: Elsevier Science Pub. Co).

1993 Il tenore di vita. Tra benessere e libertà (Venezia: Marsilio).

1994 La diseguaglianza (Bologna: Il Mulino).

Serrazanetti, M.

1933 Considerazioni sulla nostra attivita' coloniale in Somalia (Firenze: Istituto Agronomico dell'Oltre mare).

SOMMERS, M.

1995 "Representing Refugees: the Role of Elite in Burundi Refugee Society", Disasters, vol. 19 (1): 19-25.

Southall, A.

1970 "The Illusion of a Tribe", in P. G. W. GutKInd, ed., The Passing of Tribal Man in Africa (Leiden: E. J. Brill).

VAIL, L., ed.

1989 The Creation of a Tribalism in Southern Africa (London: James Currey; Berkeley: University of California Press).

\section{ABSTRACT}

The provision of international humanitarian aid, far from being a neutral intervention in the forced migrants communal identity, is an especially directive intervention characterised by a set of standard procedures. Some micromechanisms within such procedures act as to foster ethnic reinvention together with empowerment of certain groups and individuals among the refugees.

In the following article the case of the Somali Bantu refugees is analysed and ways inter-gender relations are strongly affected by the process of receiving aid during forced migrations are described. The very organisational procedure through which 
humanitarian aid is provided act as empowering and disempowering groups and individuals among the migrants; such procedure often pushes inter-gender power imbalances.

\section{RÉSUMÉ}

Invention de l'ethnicité et modification des rapports de genre chez les réfugiés somali du Kénya. - La fourniture d'une aide humanitaire internationale, loin de représenter une intervention neutre sur l'identité des migrants déplacés de force, constitue en fait une série de procédures standardisées et apppliqués de façon extrêmement directive. Certains mécanismes internes à ces procédures contribuent ainsi à favoriser la réinvention des identités ethniques de même qu'elles renforcent le pouvoir de certains groupes et individus parmi les réfugiés. Dans cet article on analyse le cas des réfugiés bantu somali et on décrit la façon dont les relations de genre sont affectées par le processus de distribution de l'aide. Les procédures par lesquelles transite l'aide humanitaire se traduisent par l'affermissement du pouvoir de certains groupes de migrants au détriment d'autres groupes et favorise les ruptures d'équilibre entre les genres.

Keyword/mots-clés: Kenya, Somalia, Bantu Somali, ethnic reinvention, forced migration, gender relations, humanitarian aid, persecution, refugee camps/Kenya, Somalie, aide humanitaire, camps de réfugiés, migrations forcée, persécution, réinvention ethnique, relations de genres, somali bantu. 